PEMBELAJAR: Jurnal Ilmu Pendidikan, Keguruan, dan Pembelajaran

Volume 1 Nomor 2 Oktober 2017

e-ISSN: 2549-9114 dan p-ISSN: 2549-9203

(Received: Agustus-2017; Reviewed: September-2017; Published: Oktober 2017)

\title{
Efektivitas Bermain Peran Untuk Pengembangan Bahasa Anak
}

\author{
Muhammad Akil Musi, Widia Winata \\ 1. Universitas Negeri Makassar, \\ Kampus Tidung Jl. Tamalate., Kota Makassar, Sulawesi Selatan \\ 2. Universitas Muhammadiyah Jakarta, \\ Jl. KH. Ahmad Dahlan, Ciputat - Cireundeu, Jakarta Selatan \\ Corresponding e-mail: akrimna@yahoo.co.id
}

\begin{abstract}
ABSTRAK: Perkembangan bahasa merupakan tahapan yang sangat penting dalam rentang kehidupan anak usia dini. Masalah dalam penelitian ini adalah rendahnya kemampuan anak dalam berbahasa yang ditandai dengan beberapa indikator perkembangan bahasa. Penelitian ini bertujuan untuk mengetahui efektifitas bermain peran baik secara makro dan mikro untuk mengembangkan bahasa anak usia dini. Metode penelitian yang digunakan adalah penelitian tindakan kelas yang pendekatannya dilakukan melalui analisis secara kuantitatif (analisis persentase) untuk menghitung jumlah dan persentase anak yang mencapai perkembangan dalam siklus I dan siklus II. Analisis kualitatif (analisis penilaian) dilakukan untuk menentukan penilaian perkembangan yang dicapai anak berupa belum berkembang (BB), mulai berkembang (MB), berkembangan sesuai harapan (BSH) dan berkembang sangat baik (BSB). Adapun teknik pengumpulan data dilakukan melalui pengamatan, wawancara dan teknik dokumentasi. Hasil penelitian menunjukkan bahwa bermain peran sangat efektif untuk mengembangkan kemampuan bahasa anak usia dini. Dalam kegiatan pembelajaran bahasa melalui bermain peran maka faktor yang harus diperhatikan adalah faktor motivasi dan minat anak usia dini.
\end{abstract}

Kata kunci: Bermain peran, perkembangan bahasa, anak usia dini.

ABSTRACT: Language development is a very important stage in the lifespan of early childhood. The problem in this study is the low ability of children in the language which is characterized by several indicators of language development. The aimed of this study was to determine the effectiveness of role-playing both macro and micro to develop the language of early childhood. The research method employed was classroom action research which approach is done through quantitative analysis (percentage analysis) to calculate the number and percentage of children who achieve the development in cycle I and cycle II. Qualitative analysis (assessment analysis) is conducted to determine the progress of children achievement in the form of not yet developed (BB), developing (MB), developing as expected (BSH) and developing very well (BSB). The data collection technique is done through observation, interview, and documentation techniques. The results show that role play is very effective for developing early childhood language skills. In language learning activities through role play then the factors that must be considered is the factors of motivation and interest of early childhood.

Keywords: Role play, language development, early childhood.

(C)2017 -Pembelajar Universitas Negeri Makassar. Ini adalah artikel dengan akses terbuka dibawah licenci CC BY-NC-4.0 (https://creativecommons.org/licenses/by-nc/4.0/ ). 


\section{PENDAHULUAN}

Sejak seorang anak terlahir hingga berusia enam tahun, berbagai tuntutan telah menyertai proses dan pertumbuhan dan perkembangannya. Masa ini adalah periode yang paling fundamental dalam perjalanan kehidupan seorang anak dengan segala potensi yang dimiliki. Ketepatan dan kesesuaian intervensi akan mengantarkan seorang anak untuk tumbuh dan berkembang secara ideal. Begitu pula sebaliknya, jika penanganan yang diberikan tidak optimal maka pentas usia emas akan menyisakan wacana.

Motenssori (Atli, 2016) dalam hal ini menegaskan bahwa pada masa perkembangannya harus menemukan dirinya sendiri. Terkait dengan hal itu, dalam kaidah kebijakan pendidikan tentang anak usia dini disebutkan bahwa dipandang perlu melakukan upaya demi membantu pertumbuhan dan perkembangan anak melalui langkah stimulasi yang kondusif. Hal ini merupakan usaha yang mutlak dilakukan sejak anak lahir agar anak memiliki kesiapan baik secara fisik dan mental ataupun perspektif jasmani dan rohani serta penyiapan anak guna pendidikan lebih lanjut (UU Sisdiknas No. 20 Tahun 2003).

Suatu adagium telah menjadi kesepakatan bersama bahwa masa dini dalam kehidupan anak adalah usia yang sangat signifikan sebab dalam rentang ini perkembangan berlangsung secara cepat dalam suatu periodik keemasan anak. Kondisi ini jelas adalah sebuah pertaruhan yang menentukan kehidupan anak sebab tak akan tergantikan oleh waktu-waktu yang lainnya. Kesalahan memberikan layanan maka akibatnya akan ditanggung oleh kehidupan anak dalam interval kehidupan berikutnya (Stanny, 2016). Bahkan sebagaimana dilansir banyak dalam kajian riset tentang anak memberikan statemen yang sangat krusial khususnya dalam bidang neurosains bahwa perkembangan kecerdasan dalam masa dini usia telah mengalami $50 \%$ bahkan sampai dengan mencapai level tingkat perkembangan yang sempurna. Hal ini jelas menjadi suatu keniscayaan demi dan untuk kehidupan anak. Menurut Piaget (Stoltz et al, 2014), kehidupan anak dalam usia dini sebenarnya merepresentasikan seluruh kehidupan anak secara holistik yang berarti bahwa apa yang ada saat ini, itulah yang akan berlangsung dikemudian hari.

Salah satu hal yang penting dalam perkembangan anak adalah perkembangan bahasa. Hal ini disebabkan karena bahasa merupakan alat komunikasi yang digunakan dalam interaksi sehari hari. Bahasa merupakan bagian dari perkembangan manusia yang tidak bisa dipisahkan sebagai alat komunikasi antar sesamanya (Lund, 2014). Penelitian tentang perkembangan bahasa anak dapat memperjelas kerangka metode pendidikan yang efektif dan membantu anak mencapai potensi penuh dalam kehidupannya (Mashburn, 2011). Untuk itu, hal pertama yang paling penting untuk dipertimbangkan adalah kemampuan manusia dalam menggunakan sejumlah tanda untuk berbicara dan berbahasa (Valian, 2009). Kemampuan ini bisa terbentuk di masa kanakkanak hingga usia lima tahun yang memungkinkan orang dewasa untuk memikirkan subjek yang berbeda dan saling berbagi. Atas dasar hal tersebut maka salah satu hal yang banyak disibukkan oleh para psikolog dan ahli di bidang pendidikan adalah cara mengembangkan bahasa anak (Pellegrini, 1991).

Menurut Datspak (2017), anak membawa kemampuan berbahasa yang ditandai dengan adanya beberapa tanda-tanda komunikasi pertama seperti mengoceh dan menangis. Dalam hal ini sesungguhnya anak menyampaikan beberapa pesan dan secara bertahap dapat memproduksi kata-kata. Hal ini terus akan berlangsung sampai anak berusia satu tahun. Selanjutnya pada proses lebih lanjut, anak akan mampu menggabungkan beberapa kata dengan cara yang luar biasa sehingga menghasilkan beberapa kalimat. Pada usia tiga tahun maka anak telah dapat berpartisipasi dalam percakapan, mengajukan pertanyaan dan menjawab pertanyaan. Hal inilah yang 
mengisyaratkan betapa bahwa dalam perkembangan anak, perkembangan bahasa sebagai bagian dari kehidupan anak harus terus dikembangkan secara optimal.

Untuk mengembangkan bahasa anak berbagai metode dapat dilakukan di lembaga pendidikan. Salah satu hal yang dapat dilakukan adalah bermain peran, baik dilakukan secara makro maupun secara mikro. Bermain peran adalah media yang tepat dalam mengajarkan anak karena dapat menawarkan suatu pembelajaran yang holistik bagi anak untuk memperoleh seperangkat pengalaman bahasa (Rodgers, S. and Evans, J., 2008).

Berbagai penelitian pun telah membuktikan bahwa melalui bermain peran maka proses belajar mengajar dapat ditingkatkan di berbagai tingkat pendidikan dengan meningkatkan motivasi dan partisipasi aktif anak (Ments, M. V., 1999). Manfaat bermain peran juga dikemukakan oleh Dick dan Carey (2001) yang menekankan bahwa bermain peran merupakan cara yang efektif untuk mengembangkan kemampuan bahasa lisan dan dapat digunakan sebagai alternatif untuk mengembangkan kemampuan bahasa anak yang dapat memungkinkan mereka dapat menjadi seorang yang memiliki kemampuan komunikasi yang memadai. Dalam permainan peran menurut Bradshaw, M. J. and Lowernstein, A. J. (2011) maka anak akan dapat belajar sambil melakukan sesuatu. Hal inilah yang akan meningkatkan nilai dan kepercayaan, keterampilan praktis seperti bernegosiasi, berdebat dan menyampaikan pendapat.

\section{Rumusan masalah dan Tujuan penelitian}

Berdasarkan hal tersebut maka mengingat pentingnya mengembangkan bahasa anak sebagai bagian yang tak terpisahkan dari kehidupan anak serta metode yang tepat dalam pengembangannya, maka perlu dilakukan kajian untuk mengetahui efektivitas penerapan bermain peran dalam upaya mengembangkan kemampuan bahasa anak. Hal ini berangkat dari studi pendahuluan mengenai analisis kebutuhan yang ditemukan bahwa kemampuan anak dalam hal berbahasa masih rendah sehingga dipandang perlu mengkaji metode yang efektif dalam proses pengembangannya. Rumusan masalah penelitian ini adalah apakah bermain peran efektif untuk mengembangkan bahasa anak usia dini. Penelitian bertujuan untuk mengetahui efektivitas bermain peran untuk mengembangkan bahasa anak usia dini. Hasil penelitian ini diharapkan dapat menjadi referensi dalam khazanah ilmu pengetahuan tentang pendidikan anak usia dini khususnya mengenai metode bermain peran dan perkembangan bahasa anak usia dini.

\section{KAJIAN PUSTAKA}

\subsection{Teori Perkembangan Bahasa}

Untuk mempelajari perkembangan bahasa anak usia dini maka terdapat sejumlah teori sebagai landasan yang mendukung antara lain teori behaviorisme. Menurut Goodwin (2008), behaviorisme berkaitan dengan perubahan perilaku dan peran lingkungan dalam perubahan ini. Dipercaya bahwa berbicara dan berbahasa adalah keterampilan dan tidak ada perbedaan antara berbicara bahasa dan perilaku lainnya. Perilaku bahasa yang dapat diamati dan mencoba menemukan hubungan antara tanggapan dan rangsangan yang memiliki asal lingkungan. Dari sudut pandang ini maka perilaku berbahasa yang efektif adalah respons yang benar terhadap stimulus. Jika respons spesifik diperkuat, perubahannya menjadi kebiasaan atau dikondisikan, dan oleh karena itu anak-anak mengulangi tanggapan tersebut.

Selanjutnya disebut dengan teori pengondisian operan adalah salah satu dari beberapa teori yang mendasari proses belajar anak. Menurut Domjan (2016) teori ini menekankan perlunya memperhatikan aspek perilaku anak dalam belajar. Pengondisian operan berdasarkan teorinya mengenai kondisi lingkungan yang membentuk perilaku dengan 
penambahan atau pengurangan penghargaan atau hukuman yang menyebabkan efek yang diinginkan atau tidak diinginkan pada suatu subjek. Melalui pemberian penghargaan dan hukuman maka perilaku yang baik dapat diperkuat sedangkan perilaku yang buruk atau tidak diinginkan dapat dihilangkan.

Teori lainnya yang adalah nativisme yang menekankan bahwa bahasa tergantung pada pemikiran dan tidak dapat digunakan untuk menukar gagasan kecuali seseorang memperoleh konsep yang diperlukan. Berdasarkan teori ini, seorang anak adalah seorang pelajar aktif yang berinteraksi dengan lingkungan untuk menciptakan struktur intelektual yang kompleks untuk memecahkan masalahnya (Fisher, 2005).

Selain itu, untuk memahami teori yang mendasari perkembangan bahasa anak maka perlu mempelajari pendekatan yang disebut dengan mediasi. Mediasi merupakan konsep penting yang harus dibahas sebab terkait proses perkembangan mental. Berdasarkan konsep ini menurut Wertsch, Cole dan Wertsch (2007), mediasi merupakan pemanfaatan tanda dan alat budaya dalam penciptaan perubahan pemikiran secara kualitatif. Oleh karena itu, mediasi adalah penggunaan sistem komunikasi dalam menunjukkan kejadian, dan karena sistem komunikasi merupakan sarana untuk berinteraksi dengan pemikiran dan gagasan, bahasa adalah sistem komunikasi yang digunakan oleh manusia untuk mengekspresikan pemikiran anak (Smidt, 2013).

Dalam hal pembelajaran bahasa, pada awalnya tindakan pembelajaran yang tidak fokus dapat disesuaikan dan dimodifikasi berdasarkan bagaimana pembelajaran bahasa dimediasi.
Dengan demikian mediasi adalah instrumen perubahan kognitif. Mediasi ini bisa berupa buku teks, materi visual, kesempatan untuk interaksi, pembelajaran langsung termasuk bermain peran (Donato dan Adair-Hauck, 1992).

\subsection{Instrumen Perkembangan Bahasa Anak Usia Dini}

Dalam tahapan perkembangan bahasa anak, setiap usia memiliki perbedaan. Hal ini berarti bahwa kemampuan anak dalam berbahasa pada umumnya mengalami perbedaan kemampuan dalam setiap usia tahapan perkembangan. Beberapa diantaranya seperti yang dikemukakan oleh Vigotsky (John, 2007) yang mengatakankan bahwa usia dua sampai tujuh tahun kemampuan bahasa anak masih sebatas egosentris yang tidak menekankan pada aspek internalisasi ucapan sehingga dalam fase perkembangan ini anak membutuh suatu hubungan atau interaksi sosial yang memadai. Sementara itu, Chomsky (Paleeri, 2011) menekankan adanya sejumlah instrumen yang merupakan perbedaan kemampuan anak dalam berbahasa pada setiap tahapan perkembangan anak.

Penelitian ini merujuk pada tahapan perkembangan bahasa sebagaimana diatur dalam Peraturan Menteri Pendidikan dan Kebudayaan (Permendikbud) Nomor 137 Tahun 2014 Tentang Standar Pendidikan Anak Usia Dini, disebutkan beberapa standar tingkat pencapaian perkembangan anak (STPPA) khususnya dalam hal perkembangan bahasa dapat dilihat pada Tabel 1di bawah ini: 
Tabel. 1. Lingkup Perkembangan Bahasa Anak Usia Taman Kanak-kanak

\begin{tabular}{lll}
\hline $\begin{array}{l}\text { Ruang Lingkup } \\
\text { Perkembangan } \\
\text { Bahasa Anak }\end{array}$ & \multicolumn{1}{c}{ Usia (tahun) } \\
\cline { 2 - 3 } & \multicolumn{1}{c}{$4-5$} & \multicolumn{1}{c}{$5-6$} \\
\hline & $\begin{array}{l}\text { Menyimak perkataan orang lain } \\
\text { (bahasa ibu atau bahasa } \\
\text { lainnya) }\end{array}$ & $\begin{array}{l}\text { Mengerti beberapa perintah } \\
\text { secara bersamaan }\end{array}$ \\
& $\begin{array}{l}\text { Mengerti dua perintah yang } \\
\text { diberikan bersamaan }\end{array}$ & $\begin{array}{l}\text { Mengulang kalimat yang lebih } \\
\text { kompleks } \\
\text { Memahami bahasa } \\
\text { Memahami cerita yang } \\
\text { dibacakan anami aturan dalam suatu } \\
\text { permainan }\end{array}$ \\
& $\begin{array}{l}\text { Mengenal perbendaharaan kata } \\
\text { Mendengar dan membedakan } \\
\text { bunyi-bunyian dalam Bahasa } \\
\text { Indonesia }\end{array}$ \\
\hline
\end{tabular}

Sumber: Permendikbud RI No. 137 Tahun 2014 Tentang Standar PAUD

\subsection{Konsepsi Bermain Peran}

Pengalaman yang menyenangkan sebagai suatu jalan dan jalur dalam bereksplorasi merupakan hakikat pembelajaran anak usia dini. Dalam kondisi demikian maka anak akan menemukan daya imajinasi dan fantasi yang kuat dan menyisakan kesan. Untuk itu, eksistensi bermain peran tidak hanya sebagai sebuah bentuk simulasi tanpa makna, melainkan mampu membawa anak pada cakrawala penjelajahan yang aktual dan faktual. Bermain peran sebagai representasi drama kehidupan anak tentunya dapat menjadi panggung yang efektif dalam mengoptimalisasi kemampuan anak terutama dalam dimensi kedirian atau pengembangan kesadaran diri.

Menurut Corey dan Corey (2006), suatu permodelan perilaku yang efektif adalah ketika seorang anak memiliki kesempatan untuk melakukan pengamatan dan replikasi. Dalam konteks bermain peran maka seorang anak akan mememerankan dalam atau pura-pura menjadi sesuatu sehingga akan menemukan di dalam sesuatu tersebut berbagai hal seperti pemahaman baru, pengalaman yang bermakna, imajinasi, daya hayal yang sesungguhnya merupakan dunia yang dicintai oleh seorang anak. Dalam hal ini, bermain peran dapat menjadi replikasi kehidupan yang dijalani oleh pemeran yang memiliki hasrat untuk menemukan banyak hal mengenai diri dan kehidupannya.

Meski demikian, bukan kemampuan dalam bermain peran yang menjadi tujuan, melainkan efek yang dibawa dalam konteks metode ini seperti serapan informasi, personalisasi peran, persepsi, serta perilaku yang kesemuanya itu akan berkontribusi terhadap jiwa sosial emosional anak yang didalamnya terdapat "diri" dalam kesadarannya. Taylor et al. (2007) menyebutnya sebagai ruang eksplorasi dan wahana untuk berpartisipasi aktif yang nyaman dan aman dalam merumuskan dan mengungkapkan rasa yang ada. Sementara De Lange, Mitchell dan Bhana (2012), menginterpretasikan sebagai jalan untuk menemukan keyakinan diri karena dalam bermain peran, anak belajar tentang mengelola diri secara efektif untuk mengantar anak menemukan kecerdasan dirinya secara personal bahkan interpersonal sebagai bagian yang penting dalam kehidupan sosialnya. 


\section{METODE PENELITIAN}

Metode yang telah digunakan dalam penelitian ini adalah penelitian tindakan kelas. Penelitian ini pada hakikatnya menurut Hong dan Lawrence (2011) adalah untuk meningkatkan mutu, proses dan hasil pembelajaran di kelas. Mills (2003) menunjukkan bahwa penelitian tindakan adalah suatu proses dimana informasi dikumpulkan dengan tujuan memperoleh wawasan, mengembangkan praktik secara reflektif yang mampu mempengaruhi perubahan positif anak. Praktik refleksi dari penelitian guru kontinyu karena guru melakukan studi mandiri dan penyelidikan untuk mengkaji kegiatan mengajarnya.

Subjek dalam penelitian ini adalah anak usia kelompok B2 (usia 5-6 tahun) Taman kanak-kanak Pertiwi Kota Makassar Provinsi Sulawesi Selatan yang berjumlah 15 orang..
Penelitian ini telah dilaksanakan dalam bentuk penelitian bersiklus. Setiap siklus masingmasing dilaksanakan tiga kali pertemuan. Pada setiap siklus pertama telah dilakukan selama tiga kali pertemuan dan pada siklus kedua juga telah dilakukan tiga kali pertemuan sampai siklus berikutnya sampai ditemukan hasil yang memadai untuk dilakukan analisa.

Pelaksanaan program dalam setiap siklus terdapat empat tahap kegiatan yang terdiri atas dari tahap perencanaan (penyiapan bahan ajar berupa Rencana Pelaksanaan Pembelajaran (RPP), media dan format penilaian), tahap pelaksanaan (proses kegiatan belajar mengajar), tahap pengamatan dan refleksi (menganalisa tindakan yang dilakukan, mengulang dan menjelaskan tujuan tujuan yang belum dicapai serta melaksanakan tindak lanjut). Adapun gambaran mengenai siklus pelaksanaan penelitian ini dapat dilihat pada gambar di bawah ini:

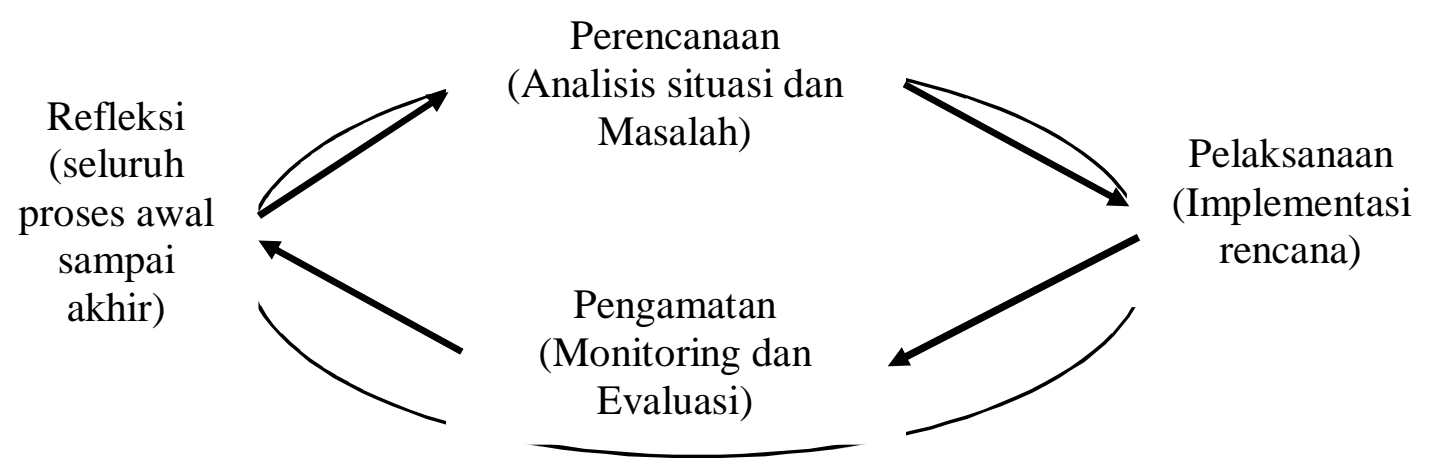

Gambar 1. Siklus Penelitian yang mengadopsi Kemmis dan Taggart (1988).

\section{HASIL DAN PEMBAHASAN}

Berdasarkan pengumpulan data yang telah dilakukan melalui pengamatan, wawancara dan teknik dokumentasi ditemukan bahwa indikator kemampuan bahasa anak pada semua pertemuan yang dilaksanakan pada siklus pertama adalah disajikan pada tabel 2. Di bawah ini: 
Tabel 2. Hasil Penilaian Kemampuan Anak pada Siklus I

\begin{tabular}{lcccc}
\hline \multirow{2}{*}{\multicolumn{1}{c}{ Indikator Kemampuan Bahasa Anak }} & \multicolumn{3}{c}{ Hasil Penilaian Perkembangan Bahasa } \\
& Anak (frekuensi) \\
\cline { 2 - 5 } & BB & MB & BSH & BSB \\
\hline Mengerti perintah secara bersamaan & 7 & 4 & 2 & 2 \\
Mengulang Kalimat yang lebih kompleks & 8 & 3 & 2 & 2 \\
Memahami aturan bermain peran & 9 & 2 & 1 & 3 \\
Memahami skenario bermain peran & 7 & 4 & 1 & 3 \\
\hline
\end{tabular}

Sumber: Hasil Penelitian, 2017.

Berdasarkan tabel 2. di atas, dapat dijelaskan bahwa hasil penilaian kemampuan berbahasa anak pada aspek kemampuan anak mengerti perintah secara bersamaan terdapat 7 anak (46,67 \%) dalam kategori belum berkembang, $4(26,67 \%)$ anak berada pada kategori mulai berkembang, 2 (13.33\%) anak pada katagori berkembang sesuai harapan dan 2 (13.33 \%) anak telah berada pada kategori berkembang sangat baik. Adapun rata-rata penilaian hasil belajar anak dapat dilihat pada tabel 3 di bawah ini:

Tabel 3. Rata-rata Penilaian Hasil belajar Anak Berdasarkan Kategori

Indikator Kemampuan Bahasa Anak

Mengerti perintah secara bersamaan

Mengulang Kalimat yang lebih kompleks

Memahami aturan bermain peran

Memahami skenario bermain peran

Jumlah

Persentase $(\%)$

Sumber: Hasil Penelitian, 2017.

Berdasarkan tabel 3 di atas, dapat dijelaskan bahwa rerata kemampuan anak pada kategori belum berkembang masih sangat tinggi yakni $56.25 \%$, kategori mulai berkembang ada $21,25 \%$, berkembang sesuai harapan terdapat $6,25 \%$ dan 16, 25 anak yang berkembang
Hasil Penilaian Perkembangan Bahasa Anak (frekuensi)

\begin{tabular}{cccc}
\hline BB & MB & BSH & BSB \\
7 & 4 & 2 & 2 \\
8 & 3 & 2 & 2 \\
9 & 2 & 1 & 3 \\
7 & 4 & 1 & 3 \\
31 & 13 & 4 & 10 \\
56.25 & 21.25 & 6.25 & 16.25 \\
\hline
\end{tabular}

sangat baik. Hal ini jelas menunjukkan bahwa kompetensi yang diharapkan atau belum mencapai ketuntasan minimal sebagaimana digambarkan pada grafik rerata penilaian di bawah ini: 


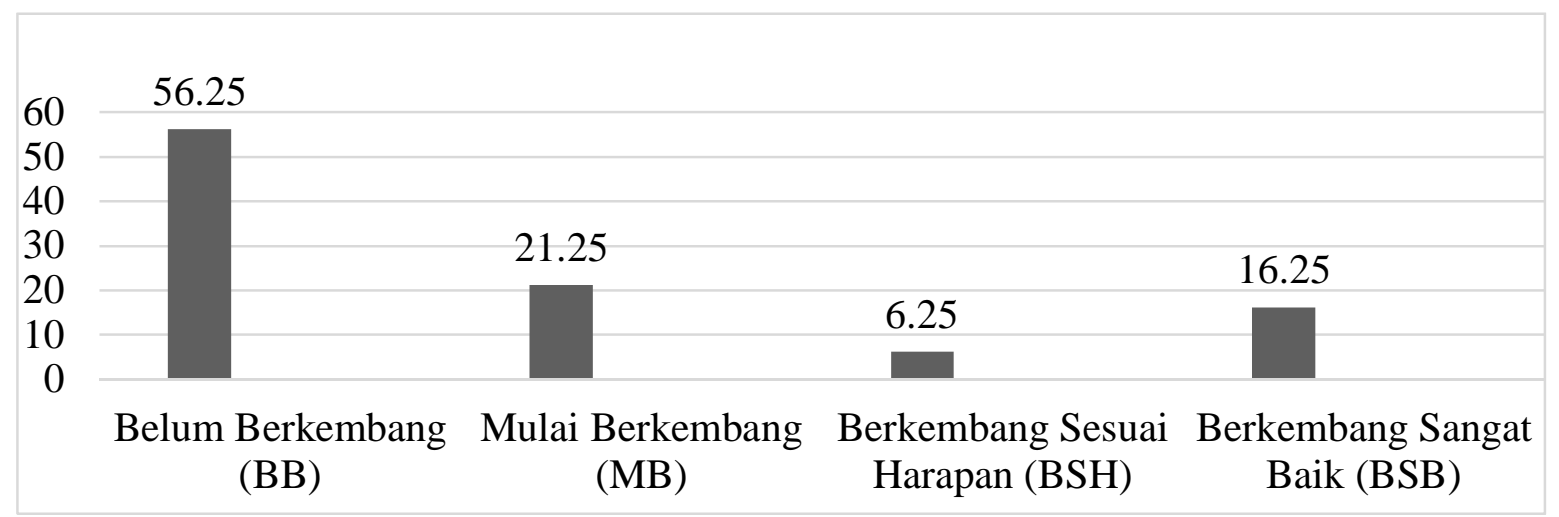

\section{Gambar 1. Hasil Penilaian Siklus I (Sumber: Hasil Penelitian, 2017)}

Rendahnya rata-rata kemampuan anak pada kategori berkembang sangat baik pada siklus I setelah dilakukan refleksi diyakini disebabkan oleh faktor motivasi baik yang berasal dari diri anak (internal) maupun yang berasal dari luar anak (eksternal) yaitu faktor lingkungan yang belum dimodifikasi dengan baik. Adapun faktor motivasi dalam belajar menurut Steinhart dan Wyer (2009) menjelaskan bahwa untuk mencapai tujuan belajar yang optimal sangat ditentukan oleh motivasi anak terutama yang berhubungan dengan teknik guru dalam mengajarkan sesuatu obyek. Lee et. al. (2010) menegaskan bahwa untuk mancapai tujuan belajar yang diharapkan maka pembelajaran harus dibuat menarik agar dapat menarik minat anak dan memiliki motivasi yang tinggi dalam belajar.

Berdasarkan hasil yang ditunjukkan pada siklus I, maka pada siklus II dilakukan upaya sebagai jawaban atas refleksi pembelajaran yang telah dilakukan terutama dalam upaya mendorong minat anak serta melakukan perbaikan pada aspek lingkungan pembelajaran anak agar lebih menarik dan menyenangkan. Adapun hasil penilaian kemampuan anak pada siklus kedua dapat dilihat pada Tabel 3 di bawah ini:

Tabel 4. Hasil Penilaian Kemampuan Anak pada Siklus II

Indikator Kemampuan Bahasa Anak

Hasil Penilaian Perkembangan Bahasa

Mengerti perintah secara bersamaan

Mengulang Kalimat yang lebih kompleks

Memahami aturan bermain peran

Memahami skenario bermain peran

Anak (frekuensi)

\begin{tabular}{cccc}
\multicolumn{4}{c}{ Anak (frekuensi) } \\
\hline BB & MB & BSH & BSB \\
2 & 1 & 1 & 11 \\
1 & 1 & 1 & 12 \\
1 & 2 & 1 & 11 \\
1 & 1 & 2 & 11 \\
\hline
\end{tabular}

Sumber: Hasil Penelitian, 2017.

Berdasarkan Tabel 4. Di atas dapat dijelaskan bahwa hasil penilaian kemampuan berbahasa anak pada aspek kemampuan anak mengerti perintah secara bersamaan hanya terdapat 2 anak $(13.33 \%)$ dalam kategori belum berkembang, 1 (6.66 \%) anak berada pada kategori mulai berkembang, 1 (6.66 \%) anak pada katagori berkembang sesuai harapan dan $11(73,33 \%)$ anak telah berada pada kategori berkembang sangat baik. Adapun rata-rata penilaian hasil belajar anak dapat dilihat pada tabel 4 di bawah ini: 
Tabel 5. Rata-rata Penilaian Hasil belajar Anak Berdasarkan Kategori

Indikator Kemampuan Bahasa Anak

Hasil Penilaian Perkembangan Bahasa

\begin{tabular}{lcccc}
\hline \multirow{2}{*}{\multicolumn{1}{c}{ Indikator Kemampuan Bahasa Anak }} & \multicolumn{3}{c}{ Hasil Penilaian Perkembangan Bahasa } \\
\cline { 2 - 5 } & BB & MB & BSH & BSB \\
Mengerti perintah secara bersamaan & 2 & 1 & 1 & 11 \\
Mengulang Kalimat yang lebih kompleks & 1 & 1 & 1 & 12 \\
Memahami aturan bermain peran & 1 & 2 & 1 & 11 \\
Memahami skenario bermain peran & 1 & 1 & 2 & 11 \\
Jumlah & 5 & 5 & 5 & 45 \\
Persentase (\%) & $8.33 \%$ & $8.33 \%$ & $8.33 \%$ & 75.00 \\
\hline
\end{tabular}

Sumber: Hasil Penelitian, 2017.

Berdasarkan tabel 5. Di atas dapat dijelaskan bahwa rerata kemampuan anak pada kategori belum berkembang masih sangat tinggi yakni $75.00 \%$, sedangkan anak yang telah berkembang sangat baik hanya mencapai 8.33 $\%$. Pada kategori lainnya yakni mulai berkembang dan berkembang sesuai harapan masing-masing $8,33 \%$ Hal ini jelas menunjukkan bahwa kompetensi yang diharapkan telah mencapai ketuntasan minimal sebagai hasil yang harus dicapai oleh anak yakni $70 \%$ anak yang berkembang sangat baik maka pembelajaran dapat dikatakan telah memenuhi ketuntasan minimal secara klasikal, seperti digambarkan pada grafik penilaian di bawah ini:

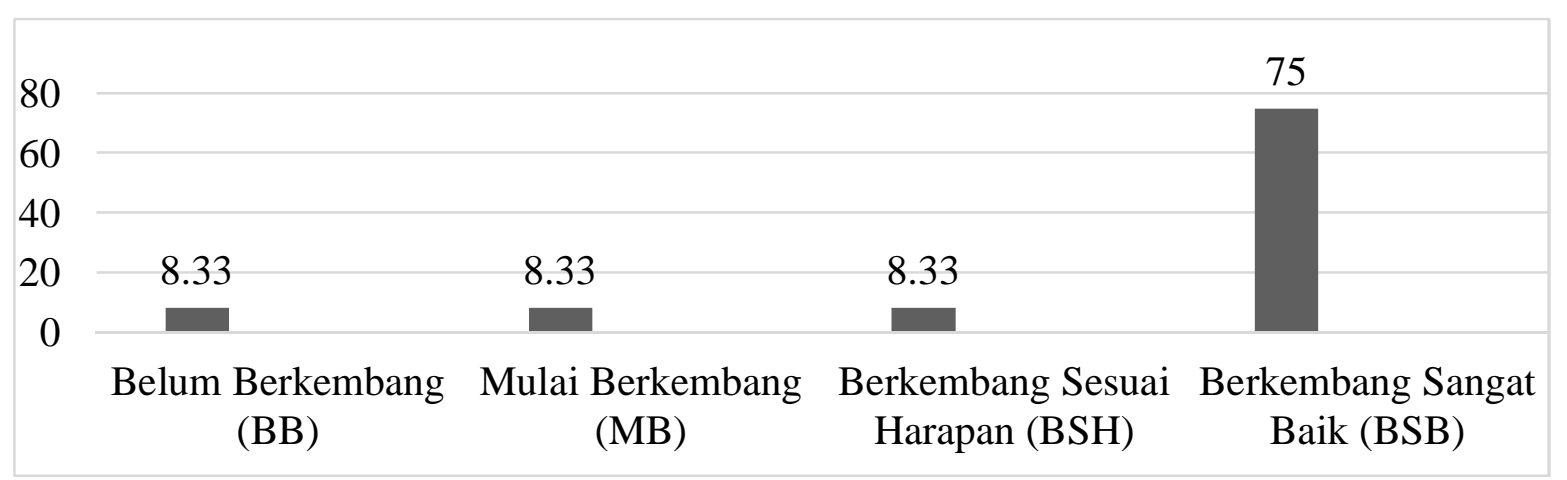

Gambar 2. Hasil Penilaian pada Siklus II (Sumber: Hasil Penilaian, 2017)

Meningkatnya hasil penilaian kemampuan sebagaimana telah dijelaskan adalah karena guru telah berhasil melakukan perbaikan dalam proses pembelajaran. Salah satu hal yang dilakukan adalah membuat anak tertarik atau dapat menumbuhkan minat anak dalam belajar. Faktor minat memang sangat memperngaruhi anak dalam kegiatan belajar mengajar. Hal ini dibenarkan oleh Arikfo (2015) yang menegaskan bahwa pengembangan minat sangat mempengaruhi tujuan pembelajaran. Sementara itu, Hoffmann (2002) mengamati bahwa, kehilangan minat terhadap masalah pembelajaran di sekolah terutama ketika anak berada dalam masa transisi. Minat dapat berkembang lebih baik indivisu terlibat dalam kegiatan pembelajaran yang 
menyenangkan. Oleh sebab itu minat pada dasarnya merupakan upaya untuk

\section{KESIMPULAN DAN SARAN}

\subsection{Kesimpulan}

1. Berdasarkan analisis data yang telah dilakukan baik dalam pendekatan kualitatif dan kuantitatif dimana rerata kemampuan anak pada kategori belum berkembang masih sangat tinggi yakni $75.00 \%$, sedangkan anak yang telah berkembang sangat baik hanya mencapai $8.33 \%$. Pada kategori lainnya yakni mulai berkembang dan berkembang sesuai harapan masingmasing $8,33 \%$. Hal ini jelas menunjukkan bahwa kompetensi yang diharapkan telah mencapai ketuntasan minimal sebagai hasil yang harus dicapai oleh anak yakni $70 \%$ anak yang berkembang sangat baik maka pembelajaran dapat dikatakan telah

\subsection{Saran}

Berdasarkan atas kesimpulan, maka hal yang perlu disarankan adalah;

1. Kegiatan bermain peran baik makro ataupun mikro sangat efektif untuk meningkatkan kemampuan bahasa anak. Selanjutnya dalam pelaksanaan bermain peran, guru harus memperhatikan beberapa faktor-faktor yang mempengaruhi keberhasilan anak dalam

\section{UCAPAN TERIMA KASIH}

Pada kesempatan ini, ucapaan terima kasih disampaikan kepada seluruh pihak yang telah membantu tahapan sejak awal dampai akhir penelitian. Ucapan ini secara khusus disampaikan kepada Kepala TK Pertiwi Makassar yang telah memberikan fasilitas melibatkan anak dalam suasana yang menyenangkan (Krapp, 2002). memenuhi ketuntasan minimal secara klasikal. Oleh karena itu dapat disimpulkan bahwa bermain peran sangat efektif dalam rangka mengembangkan kemampuan perkembangan bahasa anak.

2. Untuk mengembangkan kemampuan bahasa anak dalam aktivitas bermain peran maka hal yang perlu mendapatkan perhatian dari guru adalah faktor motivasi dan minat, sebab kedua hal ini mempengaruhi hasil belajar anak, termasuk dalam kegiatan pembelajaran untuk mengembangkan kemampuan dan kompetensi anak dalam tahapan perkembangan bahasa kegiatan belajar mengajar yaitu faktor motivasi dan minat anak.

2. Kepada peneliti yang tertarik mengkaji lebih mendalam mengenai pelaksanaan metode bermain peran dan pengkajian mengenai perkembangan bahasa anak yang lebih mendalam dan menindaklanjuti hasil penelitian ini.

berupa waktu dan tempat pelaksanaan kegiatan. Penelitian ini tentu tidak sempurna, oleh sebab itu pihak lain dapat melakukan pengembangan serta modifikasi bermain peran dan metode pengembangan bahasa anak usia dini sehingga mampu memberi khazanah pengetahuan dalam bidang dan kajian pendidikan anak usia dini. 


\section{DAFTAR PUSTAKA}

Aikpo, Ofem U. (2015). Pupils Learning Preferences and Interest Development in Learning. Journal of Education and Practice. Vol. 6 (21), 31-38.

Atli et. al. (2016). Views on Montessori Approach by Teachers Serving at Schools Applying the Montessori Approach. Eurasian Journal of Educational Research, Issue 66, 2016, 123-138.

Bradshaw, M. J. and Lowernstein, A. J. (2011).Teaching Strategies in Nursing and Related Health Profession. LLC: Jones and Barlett Publishers.

Dastpak et. al. (2017). A Comparative Study of Vygotsky's Perspectives on Child Language Development with Nativism and Behaviorism. International Journal of Languages' Education and Teaching. Volume 5, Issue 2, June 2017, 230-238.

Dick, W. and Carey, L.J.O. (2001). The Systematic Design of Instruction. Longman Publishers: Nairobi.

Domjan, Michael. (2016). Elicited Versus Emitted Behavior: Time to Abandon The Distinction. Journal of the Experimental Analysis of Behavior. Volume 105, Issue 2 March 2016, 231245.

Donato, R., dan Adair-Hauck, B. (1992). Discourse Perspectives on Formal Instruction. Language Awareness, Volume 1(2), 73-89.

Fisher, R. (2005). Teaching Children to Think. Cheltenham: Nelson Thornes.

Goodwin, C. J. (2008). A History of Modern Psychology (3rd ed.). Hoboken, NJ/ Wiley dan Sons.

Hoffmann, L. 2002. Promoting Girls' Interest and Achievement in Physics Classes for Beginners. Learning and Institution, Volume 12 (4), 447-465.
Hong, Carrie Eunyoung dan Lawrence Salika A. (2011). Action Research in Teacher Education: Classroom Inquiry, Reflection, and Data-Driven Decision Making. Journal of Inquiry dan Action in Education, 4 (2), 2011, 1-17.

John-Steiner, V. (2007). Vygotsky on Thinking and Speaking. H. Daniels, M. Cole dan J. V. Wertsch (Eds.), The Cambridge Companion to Vygotsky, Cambridge: Cambridge University Press.

Kemmis, S., McTaggart, R., dan Retallick, J. (Eds.). (2004). The Action Research Planner (2nd ed. rev.). Karachi: Aga Khan University, Institute for Educational Development.

Krapp, A. (2002). An Educational-psychological Theory of Interest and its Relation to Self-Determination Theory. In: E. Deci dan R. Ryan (Eds), The Handbook of Self-Determination Research (pp. 405427). Rochester: University of Rochester Press.

Lee, E., Mc. Inerney, D. M., Liem, G. A. D., dan Ortiga, Y. P. (2010). The Relationship Between Future Goals and Achievement Goal Orientations: An Intrinsicextrinsic Motivation Perspective. Contemporary Educational Psychology, 10, 1-16.

Lund, N. (2014). Language and Thought. New York: Routledge.

Mashburn, A.J. et al., (2011). Peer Effects on Children's Language Achievement during Pre- Kindergarten. Child Development, Vol. 80, Issue 3, 686-702.

Ments, M. V. (1999). The Effective Use of Role Play. Practical Techniques for Improving Learning. (Second edition). London: Kogan Page Limited.

Mills, G.E. (2003). Action Research: A Guide for the Teacher Researcher, 2nd Ed. Upper Saddle River NJ: Prentice Hall.

Pellegrini, A. D. (1991). Applied Child Study: A Developmental Approach. NJ: Erlbaum Associates. 
Pembelajar: Jurnal Ilmu Pendidikan, Keguruan, dan Pembelajaran. 1 (2) Oktober 2017

Rodgers, S. and Evans, J. (2008). Inside RolePlay in Early Childhood Education: Researching Young Children's Perspective. Routledge: U.S.A. Santrock Smidt, S. (2013). Introducing Vygotsky: A Guide for Practitioners and Students in Early Years Education. New York: Routledge.

Stanny, 2016. Reevaluating Bloom's Taxonomy: What Measurable Verbs Can and Cannot Say about Student Learning. Education Sciences. 2016, 6, 37, 46-67.

Steinhart, Y., dan Wyer, R. S. (2009). Motivational Correlates of Need for Cognition, European Journal of Social Psychology, 39, 608-621.
Stoltz et. al. (2014). Creativity in Gifted Education: Contributions from Vygotsky and Piaget. Creative Education, 2015, 6, 64-70.

Valian (2009). Innateness and Learnability. In E.L. Bavin (Ed.), The Cambridge Handbook of Child Language. Cambridge: Cambridge University Press.

Wertsch, J. V.; H. D., Cole, M., dan Wertsch, J. V. (2007). Mediation: The Cambridge Companion to Vygotsky. Cambridge: Cambridge University Press. 